\title{
Microbiological Screening of Platelet Concentrates in Europe
}

\author{
Marcel Prax Isabelle Bekeredjian-Ding Oleg Krut \\ Division of Microbiology, Paul Ehrlich Institute, Langen, Germany
}

\section{Keywords}

Bacterial contamination - Blood safety · Infection .

Sepsis · Platelet concentrates · Pathogen inactivation ·

Transfusion-associated infections

\section{Abstract}

The risk of transfusion-associated sepsis due to transmission of bacteria is a persistent problem in the transfusion field. Despite numerous interventions to reduce the risk, cases of bacterial sepsis following transfusion are repeatedly being reported. Especially platelet concentrates are highly susceptible to bacterial contaminations due to the growth-promoting storage conditions. In Europe, blood establishments and national authorities have implemented individual precaution measures to mitigate the risk of bacterial transmission. To obtain an overview of the different approaches, we compiled information from national authorities, blood establishments, and the current literature. Several aspects such as the shelf life of platelets, time of sampling and the applied control measures are compared between the member states. The analysis of the data revealed a broad heterogeneity of procedures on a national level ranging from platelet release without any safety testing up to mandatory screening of all platelet concentrates prior to transfusion. Despite the substantial progress made in recent years, several bacterial reports on transfusion-associated sepsis indicate that further efforts are needed to increase the safety of blood transfusions in the long term.

(c) 2019 The Author(s)

Published by S. Karger AG, Basel

\section{Introduction}

Since the first successful administration of platelets to treat hemorrhagic disorders in 1910, platelet concentrates (PC) have become one of the most effective and indispensable medicinal products [1]. This is corroborated by their listing in the World Health Organization (WHO) "List of Essential Medicines" [2]. Platelet transfusion is generally applied in cases of thrombocytopenia with platelet counts less than $10 \times 10^{9}$ counts/L caused either by severe hemorrhage, stem cell therapy, or malignancies [3]. In 2015, more than 2.8 million PC were produced by blood establishments (BE) in Europe, of which 2.2 million were actually transfused to patients [4].

Blood products are subject to regulation with the objective of quality and safety assurance for both donor and recipient. In Europe, the European Parliament and the Council adopted general guidelines for the quality and safety of blood and blood components in the directives 2002/98/EC and 2004/33/EC [5, 6]. These directives provide quality standards for the collection, testing, processing, storage, and distribution of human blood and blood components. In addition, a description of some practical principles for $\mathrm{BE}$ is provided in the regularly updated "Guide to the Preparation, Use and Quality Assurance of Blood Components" issued by the European Directorate for the Quality of Medicines \& HealthCare (EDQM) [7]. Regarding the microbial quality control of blood components, specific requirements have to be fulfilled by $\mathrm{BE}$. These recommendations ensure 
a concept to minimize the risk of microbial contamination in all blood products, and, therefore, the wording in the guidance documents is general in nature. According to these guidelines, national authorities are responsible to adopt these specifications on a national level. Moreover, individual measures that exceed the current requirements can be approved. As a result, different strategies and methodologies can be found among European countries, each having both advantages and disadvantages.

This article provides an overview of the different approaches in bacterial safety control of PC in Europe with a special emphasis on safety screening of PC. Furthermore, individual aspects affecting bacterial detection are discussed and compared between different member states (MS). A survey of European BE as well as information obtained from national authorities served as primary source for this review and was complemented by data published in the current literature.

It should, however, be noted that the information provided in this review does not cover all strategies applied in Europe in detail because individual BE in the respective MS might follow other nationally justified guidelines. However, some general variations will be highlighted and discussed in regard to their efficiency. Nevertheless, the authors emphasize that the analysis disregards other aspects such as platelet quality, logistic problems in implementing certain test methods, or cost factors.

\section{Susceptibility of PC to Microbial Contaminations}

Compared to other blood components, PC are highly susceptible to bacterial contamination. This is mainly attributed to the general PC storage conditions, which facilitate the proliferation of bacterial contaminants. The recommended storage temperature of $20-24{ }^{\circ} \mathrm{C}$ permits growth of many bacterial species originating from both the human microflora and environmental sources. Moreover, bacterial growth is promoted by the comparably high oxygen supply supported by continuous mixing of the gas-permeable PC bags. Frequently employed additives in the storage solution might serve as an additional energy source for some microorganisms resulting in a growth advantage [8]. The clinical relevance of bacterial $\mathrm{PC}$ contamination is confirmed by hemovigilance reports of transfusion incidents [9]. According to current knowledge, clinical complications caused by bacterial transmission range from mild septic reactions accompanied by fever up to severe septic shock and death of the recipients [10-12]. Moreover, delayed effects of transfusion-related bacteremia and subsequent infections cannot be entirely ruled out. Therefore, PC require adequate quality control measures to minimize the risk of bacterial transfusiontransmitted infectious diseases (TTID).
Preventative measures to decrease the risk of bacterial TTID have been implemented in the past by defining donor deferral criteria of at-risk patients, effective skin disinfection procedures, aseptic blood collection and processing by utilization of sterile equipment, predonation sampling, and leukocyte depletion. Especially the implementation of predonation sampling revealed a high potential of a simple but efficient preventive procedure. In 2 studies, diversion of the first milliliters of blood donation reduced the contamination rate from 0.35 to $0.21 \%$ for whole blood and from 0.17 to $0.05 \%$ for PC $[13,14]$. A separation of the initial $20 \mathrm{ml}$ of blood in combination with an improved skin disinfection using a two-step procedure resulted in a $77 \%$ decrease of contaminated platelets [15]. These interventions have significantly reduced the number of patients with bacterial sepsis following transfusion in the last decade. However, a low PC percentage still displays bacterial contaminations when appropriate quality control measures are performed [1618].

Asymptomatically infected donors or an inadequate disinfection of the venipuncture site are persistent sources of contamination. Referring to various publications, the rate of confirmed contaminated platelets is in the range of approximately $100-2,000$ per million PC [16, 18-20]. These contaminated PC are transfused if no further safety measures are in place. To ensure high safety standards for patients, different strategies can be pursued in order to prevent bacterial transmission via contaminated PC. However, the success rate for bacterial detection is strictly dependent on the parameters of the respective methodology.

Data that have been collected during the analysis revealed a remarkable northwest-southeast divide in Europe with respect to bacterial safety measures (Fig. 1). A rather rudimentary strategy is followed in southeastern European countries where testing is performed either only as quality control or not at all. In contrast, the majority of MS in the northwest part of Europe have implemented different safety control strategies to mitigate the risk of transfusion-associated bacterial sepsis. These individual approaches will be described and discussed in the following sections.

\section{Risk Mitigation through Platelet Storage Limitation}

The duration of storage is one of the most critical factors which has a decisive impact on the severity of bacterial contaminations in PC. In contrast to viral contaminations, bacteria have the ability to proliferate. Thus, the initial bacterial counts can increase tremendously over time. This is exemplified by the platelet transfusion-relevant bacterial strain panel that was established by the 
WHO in cooperation with members of the ISBT-TTID working party and Paul Ehrlich Institute (PEI) [21, 22]. The bacterial reference strains in this panel originate from reported transfusion incidents and grow rapidly in PC. It has further been shown that some of these strains, e.g., Klebsiella pneumoniae, Serratia marcescens, or Pseudomonas fluorescens are able to grow, starting from a few bacterial colony-forming units (CFU) to concentrations exceeding $10^{7} \mathrm{CFU} / \mathrm{ml}$ within 2 days. Consequently, worldwide, the general duration of PC storage is limited to a maximum of 7 days due to microbiological concerns.

With respect to the storage duration, quite uniform specifications apply in the different European MS. In general, the standard storage time of platelets is usually limited to a maximum of 5 days from the time of donation. In Poland, Italy, Latvia, Malta, Bulgaria, and the Czech Republic, platelets are released up to this period without bacterial screening. The time limitation is attributed to the occasional observation that particularly older platelets bear an increasing risk of bacterial transmission [11, 23]. These reports are, however, contradicted by publications questioning the strict correlation between the transfusion of older platelets and sepsis [24, 25]. A comprehensive literature review by Aubron et al. [26] revealed, that only 1 of 5 studies confirmed the assumption of an increased sepsis risk by the administration of older platelets.

Nevertheless, the suspected rise in the contamination risk for older PC was decisive for the introduction of stricter release criteria in Germany. In 2008, the German Blood Working Party decided to decrease the shelf life of platelets from 5 to 4 days (Votum 38) due to a disproportionate number of 5-day-old platelets causing transfusion reactions [27]. To avoid supply shortages, the extension of the shelf life to day 5 was authorized upon implementation of bacterial testing as a safety measure (Fig. 2). Based on hemovigilance data from 1997 to 2013, a gradual reduction in transfusion-transmitted bacterial infections was observed due to the implementation of preventive measures such as leukocyte depletion of cellular blood components and the implementation of predonation sampling [23]. Since 2008, the reduced PC storage time led to a reduction in reported transfusion incidents by approximately $50 \%$ in comparison to the period before introduction of this measure, thus, resulting in a total of 5.3 cases per $10^{6}$ platelet units. Interestingly, however, the analysis of hemovigilance data from 2005 to 2010 in Switzerland documented that the frequency of transfusiontransmitted bacterial infections was almost equally distributed among PC stored for 5 or 4 days [28]. Thus, prevention of 50\% of TTID might represent the maximum benefit to be expected from PC storage time reduction to 4 days. And, despite a considerable decrease in bacterial transmissions, the overall success of this strategy might

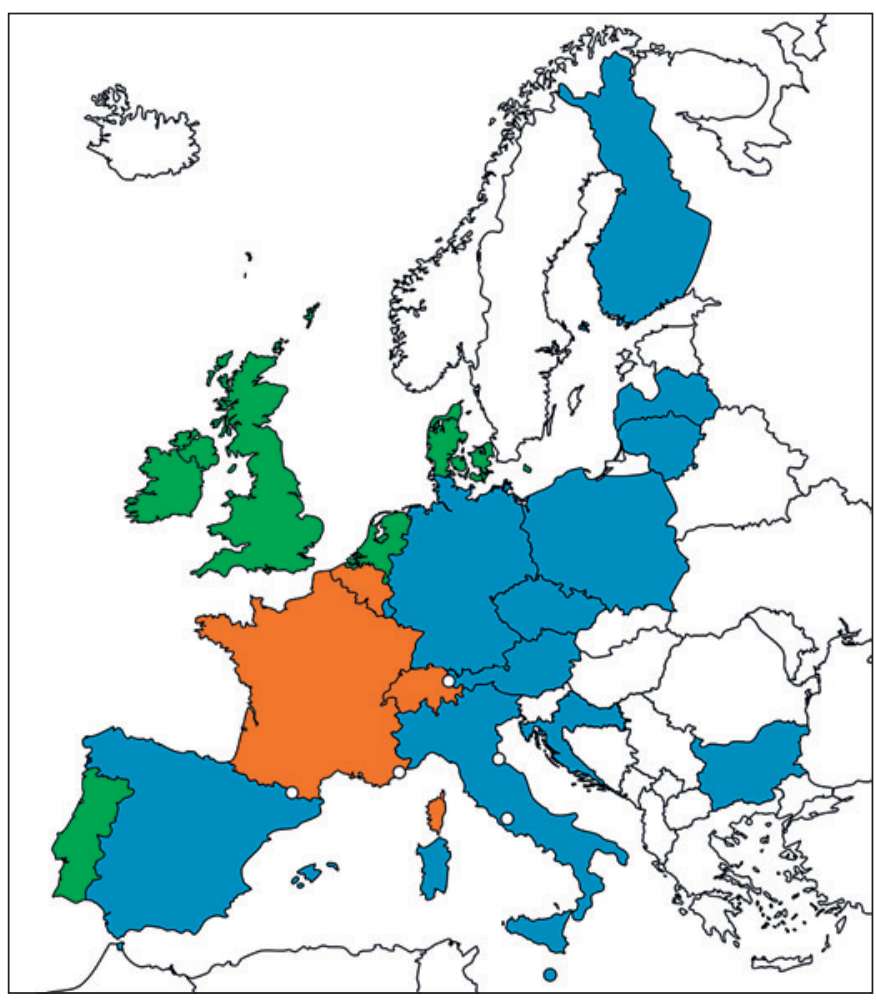

Fig. 1. Strategies applied for risk reduction of transfusion-transmitted bacterial transmission via platelets in Europe. Green, routine-based screening; orange, routine-based pathogen inactivation; blue, only partial and/or quality control testing; white, no data available; dots, mini states. The map was generated with www. mapcharts.net.

be questioned, because it can neither guarantee the absence of septic transfusion reactions nor prevent their mortality. Consequently, despite its effectiveness, when used as a stand-alone prevention measure, the reduction in the PC shelf life should be limited to less than 4 days, which would, however, have a negative impact on product availability.

\section{Mandatory Microbiological Screening by Culture-Based Methods}

In contrast to the shelf life reduction strategy, a rather proactive approach is pursued in the Netherlands, Ireland, UK, Denmark, and Portugal. Here, a national routine bacterial screening of all platelet preparations is mandatory. In general, a sample is taken from each platelet unit and inoculated in an automated culture bottle-based system. This microbiological culture system allows bacteria of contaminated platelet samples to grow in rich medium under permissive temperatures. In Europe, the 2 most common devices used by $\mathrm{BE}$ are the semiautomated blood culture systems BacT/ALERT ${ }^{\circledR}$ (bioMérieux) or 
Fig. 2. Detailed strategies of individual member states (MS) to prevent contaminated platelet concentrate (PC) transfusion. A) Shelf life reduction to 4 days with an extension to 5 days by additional testing with culture-based or rapid microbiological methods (dashed line). B) Implementation of a random quality control (QC) testing; release of platelets up to day 7 is possible in individual MS dependent on additional measures to detect bacteria (dashed lines). C) Routine culture-based screening with early sampling. A 2-bottle strategy (aerobic and anaerobic) is followed except for Denmark, where an aerobic culture bottle is used. Shelf life varies between 5 and 7 days among the respective MS. Ireland and UK allow additional testing on day 4 for shelf life extension to day 7. D) Routine culture-based screening with late sampling and a corresponding shelf life of 7 days. E) Implementation of pathogen reduction; red boxes indicate the sampling period.

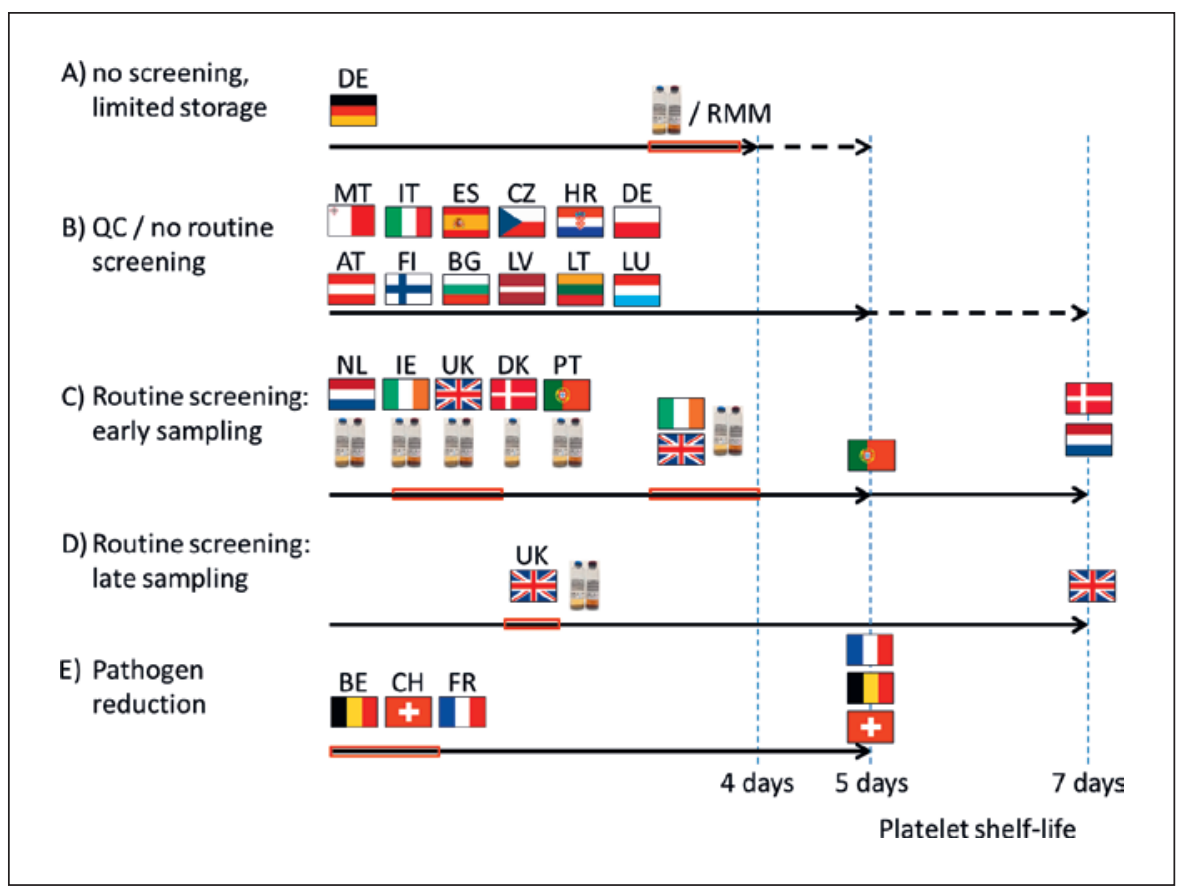

BacTec (Becton Dickinson). Both technologies analyze cell growth via the detection of $\mathrm{CO}_{2}$ as a by-product of the metabolism of bacteria in the medium. The release of $\mathrm{CO}_{2}$ leads to a colorimetric (BacT/Alert) or fluorescent (BacTec) signal, which is continuously monitored. The exact specification of the sampling and incubation procedures differs according to national guidelines and varies among the different countries.

For stratification and analysis, here, we distinguish 2 major approaches based on the sampling time, e.g., "early sampling" defined as sampling within $36 \mathrm{~h}$ after blood donation and "late sampling," when cultivation is initiated later than $36 \mathrm{~h}$. Notably, most countries with mandatory PC screening have implemented early sampling (Table 1). For instance, the time of sampling in the Netherlands is designated within a range of $18-26 \mathrm{~h}$ for pooled platelet preparations. Apheresis platelets are tested within $12 \mathrm{~h}$ after collection. In Ireland, apheresis platelets are sampled 1 day after donation (12-24 h) whereas pooled platelets are tested following the "late sampling" strategy, 1 day after pooling, which corresponds to day 2 after collection (36-48 h). In the UK, BE can choose from 2 different sampling schedules. Samples can either be taken $18 \mathrm{~h}$ after collection limiting storage duration to 5 days, or sampling can be performed at $\geq 36 \mathrm{~h}$ allowing a shelf life of 7 days. In Portugal, testing is performed $24 \mathrm{~h}$ after collection with restriction of storage time to 5 days. In Denmark, samples are taken 1 day after donation for apheresis platelets and 1 day after donation of whole blood on the day of pooling with storage duration lasting 7 days. The rationale behind this early sampling is to ob- tain microbiological results as early as possible. However, due to the low initial concentration of microbial contaminants, the detection of pathogens within the first $24 \mathrm{~h}$ bears the risk of sampling errors and false-negative results [29].

So far, the initial bacterial load of a natural contamination has not been clearly enumerated. Based on bacterial screening data, a bacterial count $<60 \mathrm{CFU} / \mathrm{bag}$ is predicted to be present in a naturally contaminated PC [30,31]. This extremely low concentration is prone to sampling errors, especially when samples are collected shortly after donation when the bacterial load is far below $1 \mathrm{CFU} / \mathrm{mL}$ and knowing that bacteria tend to grow in aggregates and are not evenly distributed in solutions. Therefore, the estimated frequency of false-negative results associated with the "early sampling" strategy is alarming: only 10 $50 \%$ of the contaminated blood cultures are detected as positive $[18,29]$.

With this reasoning, "late sampling" for bacterial detection was introduced to allow microbial contaminants to replicate and to reach concentrations above the detection limit. Furthermore, late sampling strategies allow the discrimination of replicating bacteria from residual bacteria killed by PC components, in particular complement. Currently, late sampling is implemented as a stand-alone screening procedure and criterion for PC release in the UK only. More frequently "late sampling" - often performed on day 4 or 5 of storage - serves as an additional safety measure that allows extension of the PC shelf life by BE, as is the case in Germany, Ireland, Finland, Latvia, Lithuania, Portugal, and Poland. 
Table 1. Summary of safety test strategies for platelet concentrates (PC) applied in Europe

\begin{tabular}{|c|c|c|c|c|c|}
\hline & No routine testing & Shelf life reduction & $\begin{array}{l}\text { Early sampling }(<36 \mathrm{~h}) \\
\text { culture based }\end{array}$ & $\begin{array}{l}\text { Late sampling ( }>36 \mathrm{~h}) \\
\text { culture based }\end{array}$ & Pathogen reduction \\
\hline Pro & $\begin{array}{l}\text { Cheap } \\
\text { No logistical efforts } \\
\text { Highest availability of } \\
\text { PC }\end{array}$ & $\begin{array}{l}\text { Cheap } \\
\text { Prevention of } \\
\text { transfusion of highly } \\
\text { contaminated PC }\end{array}$ & $\begin{array}{l}\text { Detection of some } \\
\text { contaminated PC } \\
\text { Increased safety for patience }\end{array}$ & $\begin{array}{l}\text { Detection of } \\
\text { contaminated PC } \\
\text { Increased safety for } \\
\text { patience } \\
\text { Possibility of an extended } \\
\text { shelf life }\end{array}$ & $\begin{array}{l}\text { Elimination of pathogens } \\
\text { High level of microbiological } \\
\text { safety }\end{array}$ \\
\hline Contra & $\begin{array}{l}\text { High risk for } \\
\text { transfusion- } \\
\text { associated sepsis }\end{array}$ & $\begin{array}{l}\text { Residual risk of } \\
\text { bacterial transmission } \\
\text { Supply shortage }\end{array}$ & $\begin{array}{l}\text { High sampling error due to } \\
\text { low inoculum or bacteria } \\
\text { Limited shelf life } \\
\text { Disposal of PC due to false- } \\
\text { positive test results } \\
\text { Additional costs }\end{array}$ & $\begin{array}{l}\text { Logistically complex } \\
\text { Disposal of PC due to } \\
\text { false-positive results } \\
\text { Additional costs }\end{array}$ & $\begin{array}{l}\text { Insufficient killing of spores } \\
\text { and/or biofilm-producing } \\
\text { bacteria } \\
\text { Possible risk of pyrogenic } \\
\text { reaction due to bacterial } \\
\text { components } \\
\text { Time critical } \\
\text { Logistically complex } \\
\text { Additional costs }\end{array}$ \\
\hline $\begin{array}{l}\text { Strategy } \\
\text { used in }\end{array}$ & $\begin{array}{l}\text { Poland, Italy, } \\
\text { Malta, Bulgaria, } \\
\text { Czech Republic }\end{array}$ & Germany & $\begin{array}{l}\text { Denmark, Portugal, } \\
\text { Netherlands, Ireland, UK }\end{array}$ & UK & Belgium, Switzerland, France \\
\hline
\end{tabular}

\section{Quarantine of PC during Screening}

Even for highly contaminated platelet samples, it takes several hours to yield a positive result in a culture-based screening process. For example, culture bottles inoculated with PC samples with a bacterial load of $>10^{8} \mathrm{CFU} / \mathrm{mL}$ of $K$. pneumoniae or Escherichia coli still require a minimum of $4 \mathrm{~h}$ to generate a positive alarm signal in aerobic and anaerobic culture bottles [32]. Similar results were obtained with gram-positive bacteria, e.g., Staphylococcus aureus or Bacillus spp., with concentrations $>10^{6} \mathrm{CFU} /$ $\mathrm{mL}$ resulting in a positive signal at a minimum incubation time of $4 \mathrm{~h}$. The time between the inoculation step and the test result might, however, be critical if platelets are released with a negative-to-date result. In order to prevent the transfusion of bacterially contaminated platelet units, PC could be quarantined for a predefined period. Such an approach is pursued in the UK, where a hold time for PC is authorized in combination with a culture-based screening approach. Using either a single or 2-test strategy, PC are put on hold for 6 or $24 \mathrm{~h}$, respectively, after the inoculation of the culture until they are released on a negativeto-date result. The implementation of such quarantine time slots allows the detection of potential contaminants without the risk of PC release on the basis of falsenegative results. In the context of the "late sampling" approach, the use of the quarantine principle as an additional safety measure should be considered. As "late sampling" is often performed after several days of storage, potential contaminants can have multiplied to significant and life-threatening levels $[22,33]$. Recently published data justify an appropriate and efficient hold period for the prevention of TTID. An extensive study was performed by Vollmer et al. [32] for the implementation of a culture-based method for shelf life extension of PC from day 4 to day 5. PC were spiked with few CFU of various bacterial isolates comprising species with both low and high pathogenicity. Within the first $24 \mathrm{~h}$ of incubation, a positive signal was obtained in all samples. The reduction in the testing period down to less than $12 \mathrm{~h}$ resulted in the detection of only $59 \%$ of bacteria from the low-pathogenicity group, whereas $100 \%$ detection of high-pathogenicity isolates was achieved. The detection rate was significantly improved to more than $97 \%$ if the detection time was increased to $18 \mathrm{~h}$. Similar results were also observed in an early sampling setting ( $24 \mathrm{~h}$ after blood donation) utilizing a 2-bottle approach and a volume of 7-10 mL [16]. These examples demonstrate that product release directly after sampling might lead to severe transfusion reactions due to highly contaminated platelet units, which can be prevented by the introduction of a hold time by a risk-based approach. However, the short quarantine only confers prevention of severe transfusionassociated sepsis. A longer hold time is necessary to ensure the identification of slow-growing bacteria and samples with a low starting inoculum as a prerequisite for the efficient prevention of clinical septic reactions.

\section{Improved Safety through Increased Sample Volume}

A low bacterial concentration, particularly shortly after blood donation, is one of the major challenges for bacterial screening methods. Parameters that can be altered to 
increase sensitivity, e.g., the minimum detection rate of contaminants, are currently limited. The sample volume is one factor that has a significant influence on the detection rate. The maximum sample volume for both semiautomated culture detection methods (BacTec and BacT/ Alert) is $10 \mathrm{~mL}$ per culture bottle according to the manufacture's specifications. Based on this volume, the theoretical detection limit of these systems would be $0.1 \mathrm{CFU} /$ $\mathrm{mL}$. However, analysis revealed a lower sensitivity of the systems when applied as routine control systems [34]. BE that have implemented culture-based screening of PC inoculate different volumes per bottle. For example, a maximum volume of $10 \mathrm{~mL}$ is used in Portugal and Denmark. Smaller volumes are inoculated in Ireland and the UK $(8 \mathrm{~mL} /$ bottle $)$ as well as in the Netherlands $(7.5 \mathrm{~mL} /$ bottle). Although the general effect of the sample volume on the detection rate is limited, an extensive data analysis revealed a significant increase of $57 \%$ for true-positive results using 8 versus $4 \mathrm{~mL}$ of sample volume [35]. An alternative to the inoculation of a fixed volume is depicted by a so-called proportional sample volume approach [36]. Based on a Poisson model, inoculation of $3.8 \%$ of the total platelet product volume might lead to an improved detection rate compared to a fixed volume of $8-10 \mathrm{~mL}$ [37]. The verification of the hypothesis revealed a 2 -fold increase in true-positive rates using the proportional sample volume strategy. It should, thus, be noted that a sample volume of $10 \mathrm{~mL}$ is sufficient for the $200-$ to $250-\mathrm{mL}$ PC unit. The maximum sample volume of $10 \mathrm{~mL}$ per bottle can be expanded using a second culture bottle, which can additionally be used to implement both aerobic and anaerobic culture conditions. Although larger sample volumes used for bacterial screening improve the detection rate, other specifications of platelet components such as minimum platelet count per unit should be considered.

\section{Anaerobic Screening - Is it Worth the Effort?}

Potential contaminants of PC comprise a broad spectrum of species that require specific growth conditions. A ranking of transfusion-transmitted bacteria considering several risk factors showed that all relevant pathogens except for Clostridium spp. can be cultivated under aerobic culture conditions [38]. In Europe, the screening of PC using a single aerobic bottle is implemented in Denmark (Fig. 2). Finnish BE perform random testing of PC with 1 aerobic bottle as a quality control. In contrast, $\mathrm{BE}$ from Ireland, Portugal, the Netherlands, and the UK use a 2-bottle strategy comprising both aerobic and anaerobic bottles. It is conceivable that strict anaerobic isolates such as Clostridium perfringens or Cutibacterium acnes (formerly Propionibacterium) will not grow under aerobic conditions. Therefore, a strategy utilizing both bottles types offers several advantages. Firstly, the use of an anaerobic culture bottle extends the bacterial spectrum that can be identified as a contamination. This benefit has been confirmed by several reports $[11,18,39,40]$. For instance, a study from NHS Blood and Transplant showed that $66 \%$ of all confirmed positive results were only detected in anaerobic culture bottles, whereas $8 \%$ were positive in an aerobic and $26 \%$ in both bottle types [17]. It should, however, be noted that if both bottles are removed as soon as one of both is flagged as positive, it is unknown whether the second bottle would have led to a positive signal afterwards. Data from Australia confirmed an increase in safety with the 2-bottle strategy as several bacterial contaminants were only detected in anaerobic culture bottles [16]. Secondly, inoculation of 2 culture bottles increases the sample volume and thereby decreases the sampling error particularly when early sampling is performed. Notably, many bacterial pathogens are facultative anaerobes and grow under aerobic and anaerobic conditions, among them S. aureus, E. coli, and Candida albicans. Moreover, some bacteria particularly from the enteric flora show even a faster detection time in anaerobic bottles compared to aerobic conditions [16]. A negative aspect connected to the anaerobic culture is the relatively high rate of falsepositive alarms leading to a withdrawal of non-contaminated PC [17]. Furthermore, the clinical relevance of anaerobic pathogens as contaminants in platelets is still under debate. For instance, $35-81.8 \%$ of confirmed positive results in anaerobic bottles are caused by $C$. acnes isolates [16]. But, to our knowledge, there are only rare reports on infections caused by $C$. acnes, which mainly focus on biofilms on iatrogenic implants [41]. Moreover, growth studies of 10 C. acnes PC isolates in platelets showed lack of proliferation, which indicates either persistence or death within 10 days of incubation [42]. Nevertheless, sporadic cases of transfusion incidents involving anaerobic bacteria have been reported. In 2017, two fatalities caused by the same $C$. perfringens isolate were documented by the Centers for Disease Control [10]. The routine safety test of these $2 \mathrm{PC}$ units by aerobic culture was negative during the whole incubation period. Although it is not clear whether an anaerobic culture would have prevented the administration of these PC, the reports of transfusionassociated fatalities involving $C$. perfringens highlight the necessity of a 2-bottle strategy [43], especially because no donor-related risk factors have been identified that would assist in identifying donors with anaerobic bacteremia.

\section{Role of Direct Methods as Safety Measures}

In addition to these conventional systems, rapid microbiological methods (RMM) represent a promising alternative for BE to minimize the risk of TTID. Examples 
of RMM comprise direct methods such as flow cytometry, amplification of nucleic acids, or detection of bacterial compounds, e.g., lipopolysaccharides or peptidoglycans. Particularly when applied shortly before administration, RMM might identify contaminated PC that were approved during the initial sampling procedure. Several systems are available on the market with different analytical sensitivities dependent on the detection principle. An overview of available methods and their test principles is provided by Störmer and Vollmer [44]. With regard to the time-to-result parameter, RMM are superior in comparison to culture-based methods. Depending on the method, results are obtained within a few minutes to hours, which allows for a fast release decision. However, in practice, RMM are only rarely used by $\mathrm{BE}$ or clinicians as final release tests. This might be due to several drawbacks of these systems such as low sensitivity, high costs, and increased hands-on time leading to logistic challenges.

In Europe, routine application of RMM as safety measures was so far only performed in Germany, where it is implemented by BE to extend the shelf life of platelets from 4 to 5 days [45]. The flow cytometry-based BactiFlow (Biomerieux) system is most frequently used by German BE, although technology based on nucleic acid amplification is approved for single BE, too. Due to a relatively short time-to-result window, platelets tested by this approach can be administered without putting them on hold. However, the implementation of RMM will not result in a complete elimination of transfusion-associated bacterial transmissions due to the relatively low sensitivity of these methods [46]. Samples with low bacterial counts will not be detected. Yet, when applied directly prior to transfusion, fatal incidents caused by highly contaminated platelet units can be prevented. Considering potential replication of $\mathrm{PC}$ pathogens, RMM results are usually valid for no more than $24 \mathrm{~h}$. Afterwards, the number of contaminating microorganisms may increase dramatically devaluating previous results for fast-growing bacteria.

\section{Septic Reactions due to False-Negative Results}

Screening of platelets using semiautomated culture systems is a valuable tool to increase patient safety, which is emphasized by several studies on method efficacy. However, positive outcomes are repeatedly overshadowed by reported transfusion-related fatalities and transfusion incidents with false-negative PC. This indicates the existence of a safety gap despite the aforementioned measures being implemented. Bacterial transmission of S. aureus was recently reported by the Northern Ireland Blood Transfusion Service in spite of the use of a semiautomat- ed culture system [47]. Further analyses suggested that biofilm formation might have been responsible for the false-negative result in the respective culture bottles. Due to adhesion of bacterial cells to the inner surface of the platelet bags, a sampling error is very likely [48]. Similar findings are reported for $S$. aureus isolates, which escaped from the screening process despite late sampling [17]. To this end, S. aureus can form aggregates by direct interaction with platelets [49]. This aggregation might increase the sampling error due to an uneven distribution of bacterial cells in the platelet bag.

Even though semiautomated bacterial detection systems provide a benefit in regard to safety, it should be stressed that a classical visual PC inspection should still be part of the routine quality control at all stages of the delivery chain. In many cases, transfusion of microbially contaminated PC was prevented due to visual anomalies, e.g., clot formation, lack of swirling, or color change $[47,50]$.

\section{Elimination of Bacterial Contaminations Using Pathogen Reduction Techniques}

Bacterial screening of PC using automated culture systems as any screening method is limited by sensitivity and specificity, i.e., by false-negative or false-positive results [16], leading to transfusion of contaminated or discarding of microbiologically safe PC, respectively [18]. Pathogen reduction $(\mathrm{PR})$ technologies as a tool to prevent transfusion-related septic infections are, therefore, worthwhile mentioning. Here, the main advantage is the simultaneous depletion of potential pathogens including bacteria, many viruses, and parasites. Two systems, the Intercept Blood System (Cerus Corp., Concord, CA, USA) and Mirasol (Terumo BCT Inc., Lakewood, CO, USA) are currently on the market, and the Theraflex system (MacoPharma, Mouvaux, France) will be submitted for market authorization presumably in 2019. All 3 systems received the CE mark approval for treatment of platelets. The general mechanism of all 3 systems is based on an irreversible damage to the bacterial DNA preventing nucleic acid replication. The mechanisms of the PR system are out of scope of the current review and described elsewhere [51, 52].

Several countries implemented PR treatment for PC. In Belgium, $\mathrm{PR}$ is performed for all platelet units and is obligatory since the royal decree of June 28, 2009. Along with PR implementation, the shelf life of platelets was reduced from 7 to 5 days due to concerns on platelet efficacy. A similar situation is found in Switzerland, where the Intercept system was generally introduced in 2011. Recently, Jutzi et al. [28] assessed the implementation of PR by comparing the number of reported adverse reac- 
tions related to both traditional and PR-treated PC. Before PR implementation, 2-4 septic reactions per year or 125 adverse reactions per million platelets units were reported. This number decreased to 0 directly after PR introduction, indicating the absence of transfusion-transmitted bacterial infection since then. After a 5-year regional test phase in France, nationwide PR implementation started in 2017 [53]. Future analysis of PR efficiency in PC in France will provide further evidence on the success of this strategy.

Similar to growth-based methods, time is a critical parameter for the successful implementation of PR. Fastgrowing bacteria can reach a high bacterial load within a short time, thereby exceeding the reduction capacity of the PR systems. In the worst case, a single bacterial cell that survived the treatment might be the cause of a lethal PC transfusion. Even if a successful elimination of all bacteria was achieved, remaining pyrogenic cell wall components from gram-negative bacteria or exotoxins may constitute a threat for recipients. For instance, PR of 15 PC $30 \mathrm{~h}$ after low-CFU inoculation revealed 1 positive $\mathrm{PC}$ on day 5 , whereas an earlier treatment $24 \mathrm{~h}$ after inoculation resulted in 100\% culture-negative PC [54]. Similar results were obtained when blood components were inoculated with higher concentrations (100-1,000 CFU/bag) of transfusion-relevant reference strains. Here, occasional contaminations following a reduction procedure due to bacterial loads $>10^{6} \mathrm{CFU} / \mathrm{ml}$ are reported [55]. Another challenge is presented by biofilm-positive isolates or spores, which show increased resistance towards PR treatment $[56,57]$. In contrast to the preferred late bacterial culture, it is, therefore, important to treat $\mathrm{PC}$ with $\mathrm{PR}$ as early as possible to avoid high bacterial loads. BE producing PR-treated platelets are required to follow the specifications and instructions given by the respective manufacturers to guarantee efficacy and safety. Taken together, use of PR methods requires establishment of a comprehensive quality assurance procedure including proficiency testing.

\section{Concluding Remarks}

Despite the implementation of numerous interventions, the risk of transfusion-associated bacterial sepsis still remains. In the European MS, different strategies from routine screening of PC to release in the absence of adequate safety measures - are applied. The latter is certainly the most controversial approach due to the implicit acceptance of an increased risk of transfusion-associated morbidity and mortality. The decrease in the number of platelet transfusion-transmitted infections, particularly in the last 2 decades, should not divert from the fact that a substantial risk for patients still exists $[10,50]$.
For instance, it is clear that the significance of the data is strictly dependent on the identification of septic transfusion reactions and their subsequent reporting. However, it is assumed that the incidence of transfusion-associated sepsis is underestimated, thereby not reflecting the real risk. Based on data from Hong et al. [58], a high proportion of transfusion-associated bacterial infections are not recognized. Active surveillance by platelet sample analysis at the time of release revealed a 10-40 times higher risk for platelet-associated bacterial transmission compared to passive surveillance. The major reason for this underreporting is that the administration of a bacterially contaminated PC does not necessarily lead to overt clinical symptoms in the recipient [47]. The outcome is influenced by several factors, e.g., pathogenicity of the strain and the bacterial count at the time of administration. Moreover, both the clinical status and the ongoing therapy of the patient, including administration of antibiotics, might affect the manifestation and severity of the reaction. Delayed infections upon transfusion of a bacterially contaminated PC cannot be excluded. To date, there is no documented evidence for such a scenario although delayed infections caused by nonsterile pharmaceuticals are known [59]. Therefore, the relatively low number of transfusion-associated sepsis cases should not provide a justification for the implementation of a "no-testing" strategy. However, several European MS enforce routine testing of PC (Fig. 1).

The efficacy of the different measures on the frequency of septic reactions described has recently been reported [59]. For instance, culture-based screening reduced the number of contaminated PC to 5.4 per million compared to 16.3 before routine screening was introduced in the UK. Focusing on adverse transfusion reactions, the number even decreased by $90 \%$ [17]. Moreover, no fatalities were reported since the implementation of culture-based screening. In Belgium, France, and Switzerland, where PR treatment for PC was introduced in recent years, no septic reactions were reported since its implementation. Compared to historical data, the rates of microbiologically contaminated PC decreased significantly from $19,82.9$, and 35.6 per million cases to zero cases in France, Switzerland, and Belgium, respectively [9].

Several safety measures are conceivable, which vary in their costs and effort. On the basis of the current knowledge, $\mathrm{PC}$ might be released without any additional testing only up to $12 \mathrm{~h}$ after platelet production. The release of platelets without further microbiological control after this time should not be regarded as state of the art and might be driven by economic arguments. In this case, PC should be subjected to quarantine for at least 18-20 h. In addition, at least $10 \mathrm{~mL}$ of sample per $250 \mathrm{~mL}$ PC should be inoculated in both aerobic and anaerobic culture bottles. If the culture remains negative after $18 \mathrm{~h}, \mathrm{PC}$ can 
be released on the negative-to-date principle with a shelf life up to 7 days.

An even higher safety level with respect to transfusionassociated bacterial transmission is provided by the implementation of PR systems. Data from pathogen-inactivated platelets have so far shown promising results on the reduction of PC transfusion-associated sepsis. Prior to the marketing authorization, numerous studies on the performance of these systems were conducted. Focusing on the efficacy of PR, all 3 systems demonstrated significant $\log$ reduction of bacteria in platelets $[60,61]$.

The Good Practice Guidelines of the EDQM stated that "(...) blood and blood components are not released for distribution, until their quality has been judged to be satisfactory and that the necessary and relevant tests have been carried out." As a consequence of the nonbinding nature of this guidance, a clear lack of harmonization of safety measures across Europe with respect to the microbiological safety of PC becomes apparent (Fig. 1). However, it is clear that the implementation of additional safety measures is associated with higher expenses, which may represent an obstacle for both MS with limited financial resources and smaller BE. Taken together, on the basis of our current knowledge, it is, however, not appropriate to omit safety measures for mitigation of microbiological quality control of blood components.

\section{Acknowledgment}

We thank all members of the section of microbiological safety at PEI and representatives of national competent authorities of EU MS for the detailed information on national guidelines.

\section{Statement of Ethics}

The authors have no ethical conflicts to disclose.

\section{Disclosure Statement}

The authors have no conflicts of interest to declare.

\section{Funding Sources}

None.

\section{Author Contributions}

M.P. and O.K. wrote the manuscript, and I.B.-D. contributed to the final manuscript.

\section{References}

1 Duke WW. The relation of blood platelets to hemorrhagic disease. By W.W. Duke. JAMA. 1983 Sep;250(9):1201-9.

2 WHO: WHO Model List of Essential Medicines: 20th List (March 2017, amended August 2017). Geneva: WHO; 2017.

3 British Committee for Standards in Haematology, Blood Transfusion Task Force. Guidelines for the use of platelet transfusions. Br J Haematol. 2003 Jul;122(1):10-23.

4 European Commission: Summary of the 2016 annual reporting of serious adverse reactions and events for blood and blood components, 2016.

5 European Parliament and the Council of the European Union: Directive 2002/98/EC of the European Parliament and of the Council of 27 Janurary 2003 setting standards of quality and safety for the collection, testing, processing, storage and distribution of human blood and blood components and amending Directive 2001/83/EC. Official J L 033, 08/02/2003 P. 0030-0040.

6 European Parliament and the Council of the European Union: Commission Directive 2004/33/EC of 22 March 2004 implementing Directive 2002/98/EC of the European Parliament and of the Council as regards certain technical requirements for blood and blood components. Official J L 091, 30/03/2004 P. 0025-0039.
7 European Directorate for the Quality of Medicines \& HealthCare (EDQM). Guide to the preparation, use and quality assurance of blood components, 19th ed. Strassbourg: EDQM; 2017.

8 Greco CA, Zhang JG, Kalab M, Yi QL, Ramirez-Arcos SM, Gyongyossy-Issa MI. Effect of platelet additive solution on bacterial dynamics and their influence on platelet quality in stored platelet concentrates. Transfusion. 2010 Nov;50(11):2344-52.

9 Benjamin RJ, Braschler T, Weingand T, Corash LM. Hemovigilance monitoring of platelet septic reactions with effective bacterial protection systems. Transfusion. $2017 \mathrm{Dec}$; 57(12):2946-57.

10 Horth RZ, Jones JM, Kim JJ, Lopansri BK, Ilstrup SJ, Fridey J, et al. Fatal Sepsis Associated with Bacterial Contamination of Platelets Utah and California, August 2017. MMWR Morb Mortal Wkly Rep. 2018 Jun;67(25): 718-22.

11 Dumont LJ, Kleinman S, Murphy JR, Lippincott R, Schuyler R, Houghton J, et al. Screening of single-donor apheresis platelets for bacterial contamination: the PASSPORT study results. Transfusion. 2010 Mar;50(3): 589-99.
12 Jacobs MR, Good CE, Lazarus HM, Yomtovian RA. Relationship between bacterial load, species virulence, and transfusion reaction with transfusion of bacterially contaminated platelets. Clin Infect Dis. 2008 Apr;46(8): 1214-20.

13 de Korte D, Marcelis JH, Verhoeven AJ, Soeterboek AM. Diversion of first blood volume results in a reduction of bacterial contamination for whole-blood collections. Vox Sang. 2002 Jul;83(1):13-6.

14 Satake M, Mitani T, Oikawa S, Nagumo H, Sugiura S, Tateyama $\mathrm{H}$, et al. Frequency of bacterial contamination of platelet concentrates before and after introduction of diversion method in Japan. Transfusion. 2009 Oct; 49(10):2152-7.

15 McDonald CP, Roy A, Mahajan P, Smith R, Charlett A, Barbara JA. Relative values of the interventions of diversion and improved donor-arm disinfection to reduce the bacterial risk from blood transfusion. Vox Sang. 2004 Apr;86(3):178-82.

16 Thyer J, Perkowska-Guse Z, Ismay SL, Keller AJ, Chan HT, Dennington PM, et al. Bacterial testing of platelets - has it prevented transfusion-transmitted bacterial infections in Australia? Vox Sang. 2018 Jan;113(1):13-20. 
17 McDonald C, Allen J, Brailsford S, Roy A, Ball J, Moule R, et al. Bacterial screening of platelet components by National Health Service Blood and Transplant, an effective risk reduction measure. Transfusion. 2017 May;57(5): 1122-31.

18 Ramirez-Arcos S, DiFranco C, McIntyre T, Goldman M. Residual risk of bacterial contamination of platelets: six years of experience with sterility testing. Transfusion. 2017 Sep; 57(9):2174-81.

19 Benjamin RJ, McDonald CP; ISBT Transfusion Transmitted Infectious Disease Bacterial Workgroup. The international experience of bacterial screen testing of platelet components with an automated microbial detection system: a need for consensus testing and reporting guidelines. Transfus Med Rev. 2014 Apr;28(2):61-71.

20 Katus MC, Szczepiorkowski ZM, Dumont LJ, Dunbar NM. Safety of platelet transfusion: past, present and future. Vox Sang. 2014 Aug; 107(2):103-13.

21 Störmer M, Arroyo A, Brachert J, Carrero H, Devine D, Epstein JS, et al. Establishment of the first international repository for transfusion-relevant bacteria reference strains: ISBT working party transfusion-transmitted infectious diseases (WP-TTID), subgroup on bacteria. Vox Sang. 2012 Jan;102(1):22-31.

22 Spindler-Raffel E, Benjamin RJ, McDonald CP, Ramirez-Arcos S, Aplin K, BekeredjianDing I, et al.; ISBT Working Party Transfusion-Transmitted Infectious Diseases (WPTTID), Subgroup on Bacteria. Enlargement of the WHO international repository for platelet transfusion-relevant bacteria reference strains. Vox Sang. 2017 Nov;112(8):71322.

23 Funk MB, Heiden M, Volkers P, Lohmann A, Keller-Stanislawski B. Evaluation of Risk Minimisation Measures for Blood Components - Based on Reporting Rates of Transfusion-Transmitted Reactions (1997-2013). Transfus Med Hemother. 2015 Jul;42(4): 240-6.

24 Kreuger AL, Rostgaard K, Middelburg RA, Kerkhoffs JH, Edgren G, Erikstrup C, et al. Storage time of platelet concentrates and risk of a positive blood culture: a nationwide cohort study. Transfusion. 2018 Jan;58(1):1624.

25 Flint A, Aubron C, Bailey M, Bellomo R Pilcher D, Cheng AC, et al. Duration of platelet storage and outcomes of critically ill patients. Transfusion. 2017 Mar;57(3):599-605.

26 Aubron C, Flint AW, Ozier Y, McQuilten Z. Platelet storage duration and its clinical and transfusion outcomes: a systematic review. Crit Care. 2018 Aug;22(1):185.

27 Koch-Institut R. Festlegung der Haltbarkeitsfrist von Thrombozytenkonzentraten mit dem Ziel der Reduktion lebensbedrohlicher septischer Transfusionsreaktionen durch bakterielle Kontamination. Berlin: Robert Koch-Institut; 2009. https://doi.org/10. 25646/30.

28 Jutzi M, Mansouri Taleghani B, Rueesch M, Amsler L, Buser A. Nationwide Implementation of Pathogen Inactivation for All Platelet Concentrates in Switzerland. Transfus Med Hemother. 2018 May;45(3):151-6.
29 Benjamin RJ, Wagner SJ. The residual risk of sepsis: modeling the effect of concentration on bacterial detection in two-bottle culture systems and an estimation of false-negative culture rates. Transfusion. 2007 Aug;47(8): 1381-9.

30 Murphy WG, Foley M, Doherty C, Tierney G, Kinsella A, Salami A, et al. Screening platelet concentrates for bacterial contamination: low numbers of bacteria and slow growth in contaminated units mandate an alternative approach to product safety. Vox Sang. 2008 Jul; 95(1):13-9.

31 Eder AF, Kennedy JM, Dy BA, Notari EP, Weiss JW, Fang CT, et al.; American Red Cross Regional Blood Centers. Bacterial screening of apheresis platelets and the residual risk of septic transfusion reactions: the American Red Cross experience (2004-2006). Transfusion. 2007 Jul;47(7):1134-42.

32 Vollmer T, Dabisch-Ruthe M, Weinstock M, Knabbe C, Dreier J. Late sampling for automated culture to extend the platelet shelf life to 5 days in Germany. Transfusion. 2018 Jul; 58(7):1654-64.

33 Desroches M, Clermont O, Lafeuillade B, Rodriguez C, Darty M, Royer G, et al. Genotypic and phenotypic characteristics of Escherichia coli involved in transfusion-transmitted bacterial infections: implications for preventive strategies. Transfusion. 2018 Aug; 58(8): 1940-50.

34 Brecher ME, Hay SN, Rose AD, Rothenberg SJ. Evaluation of BacT/ALERT plastic culture bottles for use in testing pooled whole bloodderived leukoreduced platelet-rich plasma platelets with a single contaminated unit. Transfusion. 2005 Sep;45(9):1512-7.

35 Bruhn R, Custer B, Vanderpool S, Townsend M, Kamel H, Tomasulo P. Impact of increasing sample volume from $4 \mathrm{ml}$ to $8 \mathrm{ml}$ on bacterial detection rates in apheresis platelets: a meta-analysis. Vox Sang. 2015 Apr;108(3): 318-20.

36 Kamel H, Townsend M, Bravo M, Vassallo RR. Improved yield of minimal proportional sample volume platelet bacterial culture. Transfusion. 2017 Oct;57(10):2413-9.

37 Tomasulo PA, Wagner SJ. Predicting improvement in detection of bacteria in apheresis platelets by maintaining constant component sampling proportion. Transfusion. 2013 Apr;53(4):835-42.

38 Domanović D, Cassini A, Bekeredjian-Ding I, Bokhorst A, Bouwknegt M, Facco G, et al. Prioritizing of bacterial infections transmitted through substances of human origin in Europe. Transfusion. 2017 May;57(5):1311-7.

39 Su LL, Kamel H, Custer B, Vanderpool S, Harpool D, Busch M, et al. Bacterial detection in apheresis platelets: blood systems experience with a two-bottle and one-bottle culture system. Transfusion. 2008 Sep;48(9):1842-52.

40 Pearce S, Rowe GP, Field SP. Screening of platelets for bacterial contamination at the Welsh Blood Service. Transfus Med. 2011 Feb;21(1):25-32.

41 Achermann Y, Goldstein EJ, Coenye T, Shirtliff ME. Propionibacterium acnes: from commensal to opportunistic biofilm-associated implant pathogen. Clin Microbiol Rev. 2014 Jul;27(3):419-40.
42 Störmer M, Kleesiek K, Dreier J. Propionibacterium acnes lacks the capability to proliferate in platelet concentrates. Vox Sang. 2008 Apr; 94(3):193-201.

43 McDonald CP, Hartley S, Orchard K, Hughes G, Brett MM, Hewitt PE, et al. Fatal Clostridium perfringens sepsis from a pooled platelet transfusion. Transfus Med. 1998 Mar;8(1): 19-22.

44 Störmer M, Vollmer T. Diagnostic methods for platelet bacteria screening: current status and developments. Transfus Med Hemother. 2014 Feb;41(1):19-27.

45 Sireis W, Rüster B, Daiss C, Hourfar MK, Capalbo G, Pfeiffer HU, et al. Extension of platelet shelf life from 4 to 5 days by implementation of a new screening strategy in Germany. Vox Sang. 2011 Oct;101(3):191-9.

46 Dreier J, Vollmer T, Kleesiek K. Novel flow cytometry-based screening for bacterial contamination of donor platelet preparations compared with other rapid screening methods. Clin Chem. 2009 Aug;55(8):1492-502.

47 Abela MA, Fenning S, Maguire KA, Morris KG. Bacterial contamination of platelet components not detected by BacT/ALERT ${ }^{\circledR}$. Transfus Med. 2018 Feb;28(1):65-70.

48 Greco C, Martincic I, Gusinjac A, Kalab M, Yang AF, Ramírez-Arcos S. Staphylococcus epidermidis forms biofilms under simulated platelet storage conditions. Transfusion. 2007 Jul;47(7):1143-53.

49 Fitzgerald JR, Foster TJ, Cox D. The interaction of bacterial pathogens with platelets. Nat Rev Microbiol. 2006 Jun;4(6):445-57.

50 Loza-Correa M, Kou Y, Taha M, Kalab M, Ronholm J, Schlievert PM, et al. Septic transfusion case caused by a platelet pool with visible clotting due to contamination with Staphylococcus aureus. Transfusion. 2017 May;57(5):1299-303.

51 Marschner S, Goodrich R. Pathogen Reduction Technology Treatment of Platelets, Plasma and Whole Blood Using Riboflavin and UV Light. Transfus Med Hemother. 2011; 38(1):8-18.

52 Seltsam A, Müller TH. UVC Irradiation for Pathogen Reduction of Platelet Concentrates and Plasma. Transfus Med Hemother. 2011; 38(1):43-54.

53 Cazenave JP, Isola $\mathrm{H}$, Waller $\mathrm{C}$, Mendel I, Kientz D, Laforêt M, et al. Use of additive solutions and pathogen inactivation treatment of platelet components in a regional blood center: impact on patient outcomes and component utilization during a 3-year period. Transfusion. 2011 Mar;51(3):622-9.

54 Wagner SJ, Benjamin RJ, Hapip CA, Kaelber NS, Turgeon AM, Skripchenko A, et al. Investigation of bacterial inactivation in apheresis platelets with 24 or 30 hours between inoculation and inactivation. Vox Sang. 2016 Oct; 111(3):226-34.

55 Schmidt M, Hourfar MK, Sireis W, Pfeiffer U, Göttig S, Kempf VA, et al. Evaluation of the effectiveness of a pathogen inactivation technology against clinically relevant transfusiontransmitted bacterial strains. Transfusion. 2015 Sep;55(9):2104-12. 
56 Irsch J, Lin L. Pathogen Inactivation of Platelet and Plasma Blood Components for Transfusion Using the INTERCEPT Blood System $^{\mathrm{TM}}$. Transfus Med Hemother. 2011; 38(1):19-31.

57 Taha M, Culibrk B, Kalab M, Schubert P, Yi QL, Goodrich R, et al. Efficiency of riboflavin and ultraviolet light treatment against high levels of biofilm-derived Staphylococcus epidermidis in buffy coat platelet concentrates. Vox Sang. 2017 Jul;112(5):408-16.
58 Hong H, Xiao W, Lazarus HM, Good CE, Maitta RW, Jacobs MR. Detection of septic transfusion reactions to platelet transfusions by active and passive surveillance. Blood. 2016 Jan;127(4):496-502.

59 Gershman MD, Kennedy DJ, Noble-Wang J, Kim C, Gullion J, Kacica M, et al.; Pseudomonas fluorescens Investigation Team. Multistate outbreak of Pseudomonas fluorescens bloodstream infection after exposure to contaminated heparinized saline flush prepared by a compounding pharmacy. Clin Infect Dis. 2008 Dec;47(11):1372-9.
60 Kwon SY, Kim IS, Bae JE, Kang JW, Cho YJ, Cho NS, et al. Pathogen inactivation efficacy of Mirasol PRT System and Intercept Blood System for non-leucoreduced platelet-rich plasma-derived platelets suspended in plasma. Vox Sang. 2014 Oct;107(3):254-60.

61 Mohr H, Gravemann U, Bayer A, Müller TH. Sterilization of platelet concentrates at production scale by irradiation with short-wave ultraviolet light. Transfusion. 2009 Sep;49(9): 1956-63.

\section{DÖAK 2019

\section{3. - 15. JUNI 2019, Hamburg | Visionen \& Wirklichkeit}

\section{Anmeldung zum Kongress über www.doeak2019.de}

KONGRESSPRÄSIDENTEN

Prof. Dr. Andreas Plettenberg ifi-Institut für interdisziplinäre Medizin

Zentrum Infektiologie

An der Asklepios Klinik St. Georg

Lohmühlenstr. 5, 20099 Hamburg
Prof. Dr. Hans-Jürgen Stellbrink ICH Infektionsmedizinisches

Zentrum Hamburg

Grindelallee 35, 20146 Hamburg
WISSENSCHAFTLICHE KOORDINATORIN

Prof. Dr. med. Marylyn Addo

Universitätsklinikum HamburgEppendorf (UKE)

Martinistraße 52

20246 Hamburg
KONGRESSAGENTUR

K.I.T. Group $\mathrm{GmbH}$ Kurfürstendamm 71

10709 Berlin

Tel: +49 (0)30 24603-219

Fax: +49 (0)30 24603-200

doeak2019@kit-group.org
KONGRESSORT

Schuppen 52 Australiastraße 52 20457 Hamburg 